\title{
PENGARUH KAPASITAS SUMBER DAYA MANUSIA DAN PENGENDALIAN INTERN AKUNTANSI PADA PELAPORAN KEUANGAN SATUAN KERJA PERANGKAT DAERAH (SKPD) KABUPATEN GIANYAR
}

\author{
Ni Putu Riski Martini* \\ Fakultas Ekonomi Universitas Warmadewa Denpasar \\ *E-Mail: riskimartini@gmail.com
}

\author{
DOI: $10.22225 / k r \cdot 9.2 .476 .50-62$
}

DiPublikasi: $31 / 01 / 2018$

Halaman: 50 - 62

\begin{abstract}
The current government institutions must follow accounting developments because users of information, especially the public demand that accountability and transparency be done. Local governments are obliged to publish information in the financial statements as a basis for decision making. Thus, the published information should be useful to the users. Information will be useful if the information is understood and can be used by users and users to trust the information. This study aims to examine the effect of human resource capacity and internal control on the financial reporting of regional work units in Gianyar regency. Population in this research is all employee in SKPD Government of Gianyar regency with method of determination of saturated sample with criterion of determination of sample which will be used in this research is 32 office of Local Government Device Unit (SKPD) Gianyar which carry out accounting finance function. Data analysis technique which is used in this research is multiple linier regression analysis technique. Based on the results of the analysis conducted then obtained the conclusion that the variable capacity of human resources and internal control affects the financial reporting unit of work device area in Gianyar regency.
\end{abstract}

\section{Keywords: human resource capacity and internal control}

\begin{abstract}
Abstrak
Lembaga-lembaga pemerintahan saat ini, harus mengikuti perkembangan akuntansi karena pengguna informasi khususnya masyarakat menuntut agar dilakukannya akuntabilitas dan transparansi. Pemerintah daerah berkewajiban mempublikasikan informasi dalam laporan keuangan sebagai dasar dalam pengambilan keputusan. Dengan demikian, informasi yang dipublikasikan tersebut harus bermanfaat bagi para pemakai. Informasi akan bermanfaat apabila informasi tersebut dipahami dan dapat digunakan oleh pemakai dan pemakai mempercayai informasi tersebut. Penelitian ini bertujuan meneliti pengaruh kapasitas sumber daya manusia dan pengendalian intern pada pelaporan keuangan satuan kerja perangkat daerah di Kabupaten Gianyar. Populasi dalam penelitian ini adalah seluruh pegawai di SKPD Pemerintah Kabupaten Gianyar dengan metode penentuan sampel jenuh dengan kriteria penentuan sampel yang akan digunakan dalam penelitian ini adalah 32 kantor Satuan Kerja Perangkat Daerah (SKPD) Kabupaten Gianyar yang melaksanakan fungsi akuntansi/ penatausahaan keuangan.Teknik analisis data yang digunakan dalam penelitian ini adalah teknik analisis regresi linier berganda. Berdasarkan hasil analisis yang dilakukan maka diperoleh simpulan bahwa variabel kapasitas sumber daya manusia dan pengendalian intern berpengaruh pada pelaporan keuangan satuan kerja perangkat daerah di Kabupaten Gianyar.
\end{abstract}

Kata kunci: kapasitas sumber daya manusia dan pengendalian intern.

\section{PENDAHULUAN}

Akuntansi keuangan telah mengalami perkembangan dengan pesat sesuai dengan kemajuan zaman. Lembaga-lembaga pemerintahan dan masyarakat saat ini mulai menaruh perhatian besar terhadap praktik-praktik akuntansi dibanding sebelumnya. Lembaga-lembaga pemerintahan saat ini, harus mengikuti perkembangan akuntansi karena pengguna informasi khususnya masyarakat menuntut agar dilakukannya akuntabilitas dan transparansi. Akuntabilitas diartikan sebagai hubungan antara pihak yang memegang kendali dan mengatur entitas dengan pihak yang memiliki kekuatan formal atas pihak pengendali tersebut (Sadjiarto, 2000). Dengan 
adanya akuntabilitas, pemerintah pusat maupun pemerintah daerah menjadi subyek pemberi informasi atas aktivitas dan kinerja keuangan yang diperlukan secara akurat, relevan, tepat waktu, konsisten dan dapat dipercaya (Herawaty, 2011).

Transparansi adalah prinsip yang menjamin akses atau kebebasan bagi setiap orang untuk memperoleh informasi tentang penyelenggaraan pemerintahan, yakni informasi tentang kebijakan, proses pembuatan dan pelaksanaannya, serta hasilhasil yang telah dicapai (Werimon, 2005). Pemerintah, baik pusat maupun daerah, berkewajiban menjadi subyek pemberi informasi dalam rangka pemenuhan hak-hak publik yaitu hak untuk tahu, hak untuk diberi informasi, dan hak untuk didengar aspirasinya. Pamungkas (2007) mengatakan bahwa salah satu upaya untuk mewujudkan akuntabilitas dan transparansi pengolahan keuangan negara adalah penyampaian laporan pertanggungjawaban keuangan pemerintah secara tepat waktu dan disusun dengan mengikuti standar akuntansi pemerintahan yang telah diterima secara umum. Menurut Attmore (2011) dengan mempersiapkan laporan keuangan dengan tepat waktu, pemerintah akan mampu membuat masyarakat tertarik untuk membayar pajak dan keuntungan lainnya adalah untuk akses pengambilan informasi yang berguna yang dapat digunakan untuk membuat berbagai keputusan penting mengenai pembangunan perumahan, pembangunan sekolah, dan pembangunan lain yang didanai oleh pajak.

Pemerintah daerah berkewajiban mempublikasikan informasi dalam laporan keuangan sebagai dasar dalam pengambilan keputusan. Dengan demikian, informasi yang dipublikasikan tersebut harus bermanfaat bagi para pemakai. Informasi akan bermanfaat apabila informasi tersebut dipahami dan dapat digunakan oleh pemakai dan pemakai mempercayai informasi tersebut. Bermanfaat atau tidaknya informasi hanya dapat ditentukan secara kualitas dalam hubungannya dengan keputusan pemakai dan keyakinan pemakai terhadap informasi yang disajikan tersebut (Andriani, 2010).

Amran (2009) menyatakan bahwa sumber daya manusia adalah salah satu faktor produksi yang sangat menentukan dalam keberhasilan suatu organisasi atau instansi. Manusia memegang peranan penting didalam pencapaian tujuan organisasi/instansi tersebut. Untuk mewujudkan cita-cita maupun tujuan organisasi perlu adanya sumber daya manusia yang berkualitas. Dengan adanya sumber daya manusia yang berkualitas, tentunya akan mampu mempengaruhi kualitas informasi akuntansi pada pelaporan keuangan.

Kawedar (2009) menyatakan, bahwa untuk meningkatkan kualitas transparansi dan akuntabilitas laporan keuangan pemerintah daerah maka diperlukan audit terhadap laporan keuangan oleh Badan Pemeriksa Keuangan (BPK). Audit Badan Pemerik- sa Keuangan (BPK) bertujuan memberikan pendapat/opini mengenai tingkat kewajaran informasi yang disajikan dalam laporan keuangan. Menurut Wirahadi Ahmad, dkk (2011), pemeriksaan yang dilakukan oleh BPK pada akhirnya akan menghasilkan laporan hasil pemeriksaan. Untuk mengetahui kualitas dari hasil pemeriksaan, dapat dinilai dari laporan hasil pemeriksaan Kualitas pemeriksaan tersebut sangat penting dalam kegiatan pemeriksaan, karena dengan kualitas pemeriksaan yang tinggi maka akan dihasilkan laporan hasil pemeriksaan yang dapat dipercaya sebagai dasar pengambilan keputusan. Pada Semester I Tahun 2011 BPK telah melaksanakan pemeriksaan atas laporan keuangan pemerintah daerah (LKPD) tahun 2010 pada 358 dari 524 pemerintah daerah provinsi/ kabupaten/kota. Terhadap 358 LKPD tahun 2010 BPK memberikan opini Wajar Tanpa Pengecualian (WTP) atas 32 LKPD, Wajar Dengan Pengecualian (WDP) atas 271 LKPD, Tidak Wajar (TW)kepada 12 LKPD dan Tidak Memberikan Pendapat (Disclaimer) atas 43 LKPD. Sementara itu Pada Semester II Tahun 2011, BPK telah melanjutkan pemeriksaan LKPD tahun 2010 atas 158 pemerintah daerah provinsi/kabupaten/kota. Terhadap 358 LKPD tahun 2010 BPK memberikan opini Wajar Tanpa Pengecualian(WTP) atas 2 LKPD, Wajar Dengan Pengecualian (WDP) atas 70 LKPD, Tidak Wajar (TW) kepada 14 LKPD dan Tidak Memberikan Pendapat (Disclaimer) atas 72 LKPD. Dengan demikian selama Tahun 2011, BPK telah menyelesaikan laporan hasil pemeriksaan (LPH) atas 516 LKPD Tahun 2010 dari 524 pemerintah daerah di seluruh Indonesia. BPK telah memberikan opini WTP atas 34 LKPD, WDP atas 341 LKPD, TW atas 26 LKPD, dan TMP atas 115 LKPD. Pada tahun 2011 ini opini BPK untuk LKPD Kabupaten Gianyar tahun 2010 adalah Wajar Dengan Pengecualian (WDP) yang masi tetap sama seperti LKPD tahun 2009 dan 2008.

Kepala Perwakilan BPK Provinsi Bali yaitu I Gede Kastawa, S.E., M.M., (Anonim, 2010) mengatakan bahwa beberapa LKPD Kabupaten Gianyar masih mengandung kelemahan. Karena itu, dia berharap sistem penganggaran perlu dicermati. Sebab masih ada kelemahan pengendalian internal terutama di Dinas Pendapatan Daerah. Dari pemeriksaan LKPD tahun 2009 ditemukan indikasi kerugian daerah Rp 341,61 juta dan administrasi Rp 49,98 miliar.

Berdasarkan latar belakang masalah yang telah diuraikan di atas, pokok permasalahan yang akan diteliti dalam penelitian ini adalah:

1) Apakah kapasitas sumber daya manusia berpengaruh terhadap kualitas informasi akuntansi pada pelaporan keuangan Satuan Kerja Perangkat Daerah (SKPD) Kabupaten Gianyar?

2) Apakah pengendalian intern akuntansi berpengaruh terhadap kualitas informasi akuntansi pada pelaporan keuangan Satuan Kerja Perangkat 
Daerah (SKPD) Kabupaten Gianyar?

Berdasarkan pokok permasalah diatas, maka tujuan dari penelitian ini adalah:

1) Untuk mengetahui pengaruh kapasitas sumber daya manusia terhadap kualitas informasi akuntansi pada pelaporan keuangan Satuan Kerja Perangkat Daerah (SKPD) Kabupaten Gianyar.

2) Untuk mengetahui pengaruh pengendalian intern akuntansi terhadap kualitas informasi akuntansi pada pelaporan keuangan Satuan Kerja Perangkat Daerah (SKPD) Kabupaten Gianyar.

\section{TINJAUAN PUSTAKA}

\section{A. Tinjauan Pustaka}

\section{Pengertian Akuntansi Sektor Publik}

Organisasi sektor publik saat ini tengah menghadapi tekanan untuk lebih efisien, memperhitungkan biaya ekonomi dan biaya sosial, serta dampak negatif atas aktivitas yang dilakukan. Berbagai tuntutan tersebut menyebabkan akuntansi dapat dengan cepat diterima dan diakui sebagai ilmu yang dibutuhkan untuk mengelola urusan-urusan publik (Mardiasmo, 2002:1).

Akuntansi sektor publik merupakan mekanisme teknik dan analisis akuntansi yang diterapkan pada pengelolaan dana masyarakat dari lembaga-lembaga tinggi negara dan departemen-departemen dibawahnya, pemerintah daerah, BUMN, BUMD, LSM, dan yayasan-yayasan sosial, maupun proyekproyek kerjasama sektor publik dan swasta (Bastian, 2009:6).

\section{Kapasitas Sumber Daya Manusia}

Menurut Wirawan (2009:1) Sumber Daya Manusia (SDM) merupakan sumber daya yang digunakan untuk menyinergikan sumber daya lainnya agar tujuan organisasi dapat terwujud. Tanpa SDM, sumber daya lainnya menganggur (idle) dan kurang bermanfaat dalam mencapai tujuan organisasi. Istilah SDM mencangkup semua yang terdapat dalam diri manusia antara lain terdiri atas dimensi-dimensi berikut.

1) Fisik manusia Keadaan fisik manusia meliputi tinggi-rendah atau berat-ringannya manusia, sehat-sakitnya fisik manusia, cantik-tampan atau tidaknya, serta kuat-lemahnya fisik manusia. Kemampuan fisik digunakan untuk menggerakan, mengerjakan, atau menyelesaikan sesuatu.

2) Psikis manusia Keadaan praktis atau kejiwaan manusia antara lain meliputi sehat atau sakitnya jiwa manusia, motivasi, semangat dan etos kerja, kreativitas, inovasi, dan profesionalisme manusia.
3) Sifat dan karakteristik manusia Karakteristik manusia terdiri atas kecerdasan (kecerdasan intelektual, emosional, spiritual, dan sosial), energi atau daya untuk melakukan sesuatu, bakat, dan kemampuan untuk berkembang.

4) Pengetahuan dan keterampilan manusia Pengetahuan manusia meliputi tinggi-rendahnya pendidikan, pengetahuan, keterampilan, dan kompetensi yang dimiliki manusia.

5) Pengalaman manusia Pengalaman manusia meliputi pengalaman yang berhubungan langsung atau tidak langsung dengan pekerjaan.

Winidyaningrum (2010) menyatakan bahwa kinerja sumber daya manusia adalah kemampuan seseorang atau individu, suatu organisasi (kelembagaan) atau suatu sistem untuk melaksanakan fungsi-fungsi atau kewenangannya untuk mencapai tujuannya secara efektif dan efisien. Kapasitasnya harus dilihat sebagai kemampuan untuk mencapai kinerja, untuk menghasilkan keluarankeluaran (output) dan hasil-hasil (outcomes).

Pada umumnya seseorang memiliki kemauan tanpa kemampuan, atau kemampuan tanpa kemauan, atau bahkan tidak dua-duanya. Untuk tipe yang terakhir, bisa menyebabkan organisasi runtuh atau bangkrut, karena penyangganya (manusia sebagai pelaku organisasi) tidak mampu, tidak mau bekerja keras dengan sistem yang sehat, tidak berkoordinasi dengan orang lain, dan sebagainya (Kushandajani, 2008).

Hassan (2010) mengatakan munculnya e-bisnis dan revolusi internet, kemajuan teknologi yang cepat, dan globalisasi menyebabkan sumber daya manusia hampir selalu menjadi permasalahan dalam tantangan ini. Oleh karena itu, program sumber daya manusia dan kebijakan harus menunjukkan bagaimana organisasi telah diarahkan sehingga mampu memenuhi tantangan. Organisasi yang sukses menunjukkan bahwa mereka telah mampu merancang sistem sumber daya manusia yang efektif.

\section{Sistem Pengendalian Intern}

Arfianti (2011) mengatakan bahwa pengendalian intern dapat didefinisikan sebagai suatu proses yang dipengaruhi oleh sumber daya manusia dan sistem teknologi informasi yang dirancang untuk membantu organisasi mencapai suatu tujuan tertentu. Pengendalian intern merupakan suatu cara untuk mengarahkan, mengawasi, dan mengukur sumber daya suatu organisasi, serta berperan penting dalam pencegahan dan pendeteksian penggelapan (fraud).

Pengendalian internal adalah suatu proses berulang untuk menemukan masalah, memecahkan masalah, menemukan masalah baru, dan memecahkan masalah baru tersebut (Wang, 2010). Menurut Curtis et all (2000) pengendalian internal dapat didefiniikan sebagai proses yang dipengaruhi oleh dewan 
entitas direksi, manajemen, dan personil lainnya, dirancang untuk memberikan keyakinan memadai tentang pencapaian tujuan dalam kategori efektivitas dan efísiensi operasi, keandalan pelaporan keuangan dan memenuhi hukum dan peraturan.

Elbannan (2009) mengatakan pengendalian intern merupakan bagian untuk memastikan keuangan tersebut dapat diandalkan dalam pelaporan. Pengendalian yang rendah akan membuat lebih rendah kualitas laporan keuangan perusahaan yang menimbulkan informasi risiko, premi risiko, dan menimbulkan biaya modal.

Berdasarkan PP No. 60 tahun 2008, tujuan Sistem Pengendalian Intern Pemerintah (SPIP) adalah memberikan keyakinan yang memadai bagi tercapainya efektivitas dan efisiensi pencapaian tujuan penyelenggaraan pemerintahan negara, keandalan pelaporan keuangan, pengamanan asset negara, dan ketaatan terhadap peraturan perundangundangan. Unsur-unsur sistem pengendalian intern pemerintahan terdiri dari:

1) Lingkungan pengendalian Pimpinan instansi pemerintah wajib menciptakan dan memelihara lingkungan pengendalian yang menimbulkan perilaku positif dan kondusif untuk penerapan sistem pengendalian intern dalam lingkungan kerjanya.

2) Penilaian risiko Pimpinan instansi pemerintah wajib melakukan penilaian risiko yang terdiri dari identifikasi risiko dan analisis risiko. Dalam rangka penilaian risiko, pimpinan instansi pemerintah menetapkan tujuan instansi pemerintah dan tujuan pada tingkatan kegiatan.

3) Kegiatan pengendalian Pimpinan instansi pemerintah wajib menyelenggarakan kegiatan pengendalian sesuai dengan ukuran, kompleksitas, dan sifat dari tugas dan fungsi instansi pemerintah yang bersangkutan.

4) Informasi dan komunikasi Pimpinan instansi pemerintah wajib mengidentifikasi, mencatat, dan mengkomunikasikan informasi dalam bentuk dan waktu yang tepat.

5) Pemantauan pengendalian intern. Pimpinan Instansi Pemerintah wajib melakukan pemantauan Sistem Pengendalian Intern. Pemantauan Sistem Pengendalian Intern dilaksanakan melalui pemantauan berkelanjutan, evaluasi terpisah, dan tindak lanjut rekomendasi hasil audit dan review lainnya.

\section{B. Hipotesis}

Hipotesis merupakan jawaban sementara dari pokok permasalahan penelitian yang akan diuji kebenarannya. Berdasarkan pada rumusan masalah, tujuan penelitian, dan kajian teori yang relevan atau- pun hasil penelitian sebelumnya maka hipotesis yang diajukan adalah sebagai berikut.

1) Pengaruh kapasitas sumber daya manusia terhadap kualitas informasi akuntansi pada pelaporan keuangan Satuan Kerja Perangkat Daerah (SKPD) Kabupaten Gianyar. Fontanella (2010) mengatakan kapasitas SDM merupakan salah satu elemen kunci dalam penyediaan dan pemanfaatan laporan keuangan pemerintah. Di Indonesia, kesiapan SDM pemerintah menuju tata kelola keuangan Negara yang akuntabel dan transparan masih menjadi dilemma. Berdasarkan Kepmendagri Nomor 29 Tahun 2002, tentang pedoman tentang pengurusan, pertanggungjawaban dan pengawasan keuangan daerah serta tatacara penyusunan Anggaran Pendapatan dan Belanja Daerah, pelaksanaan tata usaha keuangan daerah dan penyusunan Perhitungan Anggaran Pendapatan dan Belanja Daerah dengan Keputusan Menteri dibutuhkan dukungan dari teknologi dan sumber daya manusia yang memiliki latar belakang pendidikan khususnya dalam bidang akuntansi yang memadai. Adanya sumber daya manusia yang berkualitas, maka akan mempermudah dalam pelaksanaan fungsi akuntansi yang ada sehingga informasi akuntansi sebagai produk dari sistem akuntansi bisa berkualitas. Namun, masih banyak pemahaman pegawai terhadap tugas dan fungsinya sehingga terjadi hambatan di dalam pengolahan data yang berdampak pada keterlambatan penyelesaian tugas, salah satunya dalam penyajian laporan keuangan. Keterlambatan ini juga dapat menyebabkan Informasi yang dihasilkan menjadi kurang atau tidak memiliki kualitas, sebagaimana masih banyak ditemui dalam pelaporan keuangan pemerintah dalam hal ini laporan keuangan Satuan Kerja Perangkat Daerah (SKPD) Kabupaten Gianyar. Berdasarkan uraian di atas, maka hipotesis 1 penelitian ini adalah sebagai berikut.

\section{$\mathrm{H}_{1}$ : $\quad$ Kapasitas sumber daya manusia berpengaruh positif terhadap kualitas in- formasi akuntansi.}

2) Pengaruh pengendalian intern akuntansi terhadap kualitas informasi akuntansi pada pelaporan keuangan Satuan Kerja Perangkat Daerah (SKPD) Kabupaten Gianyar. Menurut Jokipii (2010) Pengendalian internal mempengaruhi banyak proses dalam suatu organisasi dan langkah-langkah kinerja tradisional yang handal, yang dapat diklaim untuk mengukur kinerja karena sistem pengendalian internal tidak dapat diidentifikasi dalam literatur. Menurut Rittenberg (2007) mempertahankan pengendalian internal yang efektif tidaklah statis. Organisasi harus memperhtikan pengendalian yang akan berubah-ubah dari waktu ke waktu sebagai risiko dan perubahan proses. Dengan demikian setiap organisasi harus memiliki proses untuk memperbarui pengendalian secara optimal. Dalam kenyataannya masih ban- 
yak laporan keuangan belum memenuhi kualitas informasi yang baik. Hal tersebut dapat dilihat dari penyimpangan-penyimpangan dan kebocoran yang masih ditemukan dalam laporan keuangan akibat pengendalian yang kurang efektif. Bila dikaitkan dengan pemerintahan, pengendalian internal ini sangat perlu diperhatikan mengingat banyak kasus mengenai belum andalnya laporan keuangan pemerintah dalam hal ini laporan keuangan Satuan Kerja Perangkat Daerah (SKPD) Kabupaten Gianyar karena pengendalian internalnya yang masih lemah . Berdasarkan uraian di atas, maka hipotesis 3 penelitian ini adalah sebagai berikut.

\section{$\mathrm{H}_{2}$ : $\quad$ Pengendalian intern akuntansi berpengaruh positif terhadap kualitas in- formasi akuntansi}

\section{III.METODE PENELITIAN}

\section{A. Tempat dan Objek Penelitian}

Penelitian ini dilakukan di Kabupaten Gianyar Provinsi Bali yang akan dilakukan pada Kantor Satuan Kerja Perangkat Daerah (SKPD) Kabupaten Gianyar yaitu:

1) Dinas Daerah, terdiri dari:

a) Dinas Pendidikan, Pemuda dan Olahraga

b) Dinas Kesehatan

c) Dinas Pekerjaan Umum

d) Dinas Sosial

e) Dinas Tenaga Kerja dan Transmigrasi

f) Dinas Perhubungan, Informasi dan Komunikasi

g) Dinas Kependudukan dan Catatan Sipil

h) Dinas Kebudayaan

i) Dinas Pariwisata

j) Dinas Koperasi, Usaha Kecil dan Menengah

k) Dinas Perindustrian dan Perdagangan

1) Dinas Pertanian, Perhutanan dan Perkebunan

m) Dinas Peternakan, Perikanan dan Kelautan

n) Dinas Pendapatan

o) Dinas Kebersihan dan Pertamanan

2) Lembaga Teknis, terdiri dari:

a) Badan Kesatuan Bangsa, Politik dan Perlindungan Masyarakat

b) Badan Pemberdayaan Perempuan dan Keluarga Berencana

c) Badan Lingkungan Hidup

d) Badan Pelayanan Perijinan Terpadu

e) Badan Pemberdayaan Masyrakat Desa f) Badan Kepegawaian Daerah

g) Rumah Sakit Umum Daerah Sanjiwani

h) Kantor Perpustakaan, Arsip dan Dokumentasi

i) Badan Perencanaan Pembangunan Daerah

j) Satuan Polisi Pamong Praja

4) Kecamatan-kecamatan, terdiri dari:
a) Kecamatan Gianyar
b) Kecamatan Ubud
c) Kecamatan Tegallalang
d) Kecamatan Sukawati
e) Kecamatan Blahbatuh
f) Kecamatan Tampaksiring
g) Kecamatan Payangan

Lokasi ini dipilih dengan pertimbangan bahwa Laporan Keuangan Pemerintah Daerah (LKPD) Kabupaten Gianyar masih mengandung kelemahan. Hal tersebut dapat dilihat dari opini BPK yaitu wajar dengan pengecualian selama tiga tahun terakhir. Untuk itu diperlukan sumber daya manusia yang berkualitas, pemanfaatan yang maksimal terhadap teknologi informasi serta pengendalian intern yang efektif sehingga tercipta laporan keuangan yang berkualitas. Pertimbangan lain pemilihan lokasi ini adalah penelitian mengenai pengaruh kapasitas sumber daya manusia, pemanfaatan teknologi informasi, dan pengendalian intern akuntansi terhadap kualitas informasi akuntansi pada pelaporan keuangan Satuan Kerja Perangkat Daerah (SKPD) Kabupaten Gianyar belum pernah dilakukan di Kabupaten Gianyar.

\section{B. Populasi dan Metode Penentuan Sampel}

Populasi adalah wilayah generalisasi yang terdiri atas obyek/subyek yang mempunyai kualitas dan karakteristik tertentu yang ditetapkan oleh peneliti untuk dipelajari dan kemudian ditarik kesimpulanya (Sugiyono, 2011:80). Populasi dalam penelitian ini adalah 32 kantor Satuan Kerja Perangkat Daerah (SKPD) Kabupaten Gianyar yang melaksanakan fungsi akuntansi/penatausahaan keuangan.

Sampel adalah bagian dari jumlah dan karakteristik yang dimiliki oleh populasi tersebut (Sugiyono, 2011:81). Metode penentuan sampel yang digunakan adalah sampel jenuh, yang merupakan teknik penentuan sampel bila semua anggota populasi digunakan sebagai sampel (Sugiyono, 2011:85). Hal ini dilakukan karena populasi relatif kecil. Kriteria penentuan sampel yang akan digunakan dalam penelitian ini adalah 32 kantor Satuan Kerja Perangkat Daerah (SKPD) Kabupaten Gianyar yang melaksanakan fungsi akuntansi/penatausahaan keuangan. 


\section{Identifikasi Variabel}

Variabel dalam penelitian ini, dapat dikelompokan sebagai berikut.

1) Variabel terikat atau dependen variabel (Y) Yaitu variabel yang dipengaruhi atau yang menjadi akibat karena adanya variabel-variabel bebas (Sugiyono, 2011:39). Variabel terikat (Y) dalam penelitian ini adalah kualitas informasi akuntansi.

2) Variabel bebas atau independen (X) Yaitu variabel yang mempengaruhi atau menjadi sebab perubahannya atau timbulnya variabel dependen (terikat) (Sugiyono,2008:59). Variabel bebas (X) dalam penelitian ini antara lain :

a) Kapasitas Sumber Daya Manusia

b) Pengendalian Intern Akuntansi

\section{Definisi Operasional Variabel}

1) Kualitas informasi akuntansi (Y) adalah informasi akuntansi memiliki kualitas relevan, andal, dapat dibandingkan dan dapat dipahami. Indikator yang digunakan dalam mengukur kualitas informasi akuntansi dalam penelitian ini yaitu kemampuan informasi untuk memberikan keyakinan bahwa informasi tersebut benar atau valid dan tersedianya informasi bagi pembuat keputusan pada saat dibutuhkan sebelum informasi tersebut kehilangan kekuatan untuk mempengaruhi keputusan (Indriasari dan Ertambang Nahartyo, 2008). Kualitas informasi akuntansi diteliti menggunakan skala likert dengan 13 pernyataan dari skala 1 sampai 4 .

2) Kapasitas sumber daya manusia $\left(X_{1}\right)$ adalah kemampuan seseorang atau individu, suatu organisasi (kelembagaan), atau suatu sistem untuk melaksanakan fungsi-fungsi atau kewenangannya untuk mencapai tujuannya secara efektif dan efisien. Kapasitas dapat dilihat sebagai kemampuan untuk mencapai kinerja, untuk menghasilkan keluaran-keluaran (outputs) dan hasil-hasil (outcomes). Indikator yang digunakan dalam mengukur kapasitas sumber daya manusia dalam penelitian ini yaitu kemampuan baik dalam tingkatan individu, organisasi/kelembagaan, maupun sistem untuk melaksanakan fungsi-fungsi atau kewenangannya untuk mencapai tujuannya secara efektif dan efisien (Indriasari dan Ertambang Nahartyo, 2008). Kapasitas sumber daya manusia diteliti menggunakan skala likert dengan 10 pernyataan dari skala 1 sampai 4.

3) Pengendalian intern akuntansi $\left(X_{3}\right)$ merupakan pengendalian intern yang meliputi struktur organisasi, metode, dan ukuran-ukuran yang dikoordinasikan untuk menjaga kekayaan organisasi, mengecek ketelitian dan keterandalan data akuntansi, mendorong efisiensi, dan dipatuhinya kebijakan pimpinan. Indikator yang digunakan dalam mengukur pengendalian intern akuntansi dalam penelitian ini yaitu bagian dari pengendalian intern yang meliputi rencana organisasi, prosedur, dan catatan yang dirancang untuk menjaga keterandalan data akuntansi (Indriasari dan Ertambang Nahartyo, 2008). Pengendalian intern akuntansi diteliti menggunakan skala likert dengan 12 pernyataan dari skala 1 sampai 4 .

\section{E. Metode Pengumpulan Data}

Metode pengumpulan data yang digunakan dalam penelitian ini adalah metode survey dengan teknik kuesioner. Kuesioner dalam penelitian ini menggunakan modifikasi kuesioner Urban (2001), Indriantoro\&Supomo (2002) dan Igbaria at.al (1997). Hasil jawaban kemudian diukur dengan menggunakan skala Likert modifikasi, yaitu pilihan jawaban responden diberi nilai dengan skala 4 poin, skor tertinggi adalah 4 (empat) dan skor terendah adalah 1 (satu). Hal ini dilakukan untuk menghindari bias jawaban apabila menggunakan skala 5 (lima) poin, dimana responden cenderung memilih jawaban yang netral untuk pertanyaan atau pernyataan yang meragukan bagi responden. Jika diberikan kategori jawaban di tengah, maka data penelitian akan banyak hilang sehingga akan mengurangi banyaknya informasi yang dapat dijaring dari responden (Badera, 2008).

Modifikasi skala Likert ini mengacu pada pendapat Hadi (1991) untuk beberapa alasan berikut: Pertama, pemberian kategori tengah memberikan arti ganda atau multi interpretable. Kedua, tersedianya kategori jawaban tengah menimbulkan kecendrungan jawaban tengah (central tendency effect) bagi auditor yang memiliki keraguan dalam menanggapi pernyataan. Ketiga, jika disediakan kategori jawaban tengah akan menghilangkan banyak informasi dari para auditor. Kriyantono (2008) juga menyatakan skala Likert dapat menghilangkan jawaban ragu-ragu karena responden memiliki kecendrungan untuk memilih jawaban yang aman, selain juga dapat menghilangkan banyak data dalam riset.

\section{F. Teknik Analisis Data}

\section{Regresi Linier Berganda}

Teknik analisis data yang dipergunakan untuk memecahkan masalah dalam penelitian ini adalah teknik analisis linear berganda. Menurut Ghozali (2011:96) teknik analisis analisis linear berganda digunakan untuk mengetahui ketergantungan suatu variabel terikat terhadap satu atau lebih variabel bebas dengan atau tanpa variabel moderator. Analisis ini juga dapat menduga besar arah dari hubungan tersebut serta mengukur derajat keeratan hub- 
ungan antara satu variabel terikat dengan satu atau lebih variabel bebas. Adapun model regresi linear berganda dengan menggunakan persamaan sebagai berikut.

$\mathrm{Y}=\alpha+\beta_{1} \mathrm{X}_{1}+\beta_{2} \mathrm{X}_{2}+\beta_{3} \mathrm{X}_{3}+\mu$

Keterangan:

$\mathrm{Y}=$ Kualitas informasi akuntansi

$\alpha \quad=$ konstanta

$\beta_{1} \beta_{2} \beta_{3} \quad=$ koefisien regresi

$\mathrm{X}_{1} \quad=$ kapasitas sumber daya manusia

$\mathrm{X}_{2} \quad=$ pemanfaatan teknologi informasi

$\mathrm{X}_{3} \quad=$ pengendalian intern akuntansi

$\mu \quad=$ error

Dari hasil analisis regresi akan diamati koefisien $\mathrm{R}$ square $\left(\mathrm{R}^{2}\right)$, uji kelayakan model $\left(\mathrm{F}_{\text {test }}\right)$ dan uji statistik $\mathrm{t}\left(\mathrm{t}_{\text {test }}\right)$. Penjelasannya adalah sebagai berikut.

a) Koefisien Determinasi $\left(\mathrm{R}^{2}\right)$ Koefisien determinasi $\left(R^{2}\right)$ digunakan untuk mengukur seberapa jauh kemampuan model dalam menerangkan variasi variabel dependen. Nilai $R^{2}$ memiliki kelemahan, yaitu dengan bertambahnya variabel bebas, nilai $\mathrm{R}^{2}$ akan meningkat walaupun variabel yang ditambahkan tersebut bukan bagian dari model. Untuk menghindari adanya kelemahan ini, maka akan lebih baik menggunakan nilai adjusted $\mathrm{R}^{2}$ (Ghozali, 2011:97).

b) Uji F Uji statistik F bertujuan untuk mengetahui kelayakan model regresi linear berganda sebagai alat analisis yang menguji pengaruh variabel bebas pada variabel terikat.

c) Uji $\mathrm{t}\left(\mathrm{t}_{\text {test }}\right)$ Uji statistik t pada dasarnya menunjukkan seberapa jauh pengaruh satu variabel penjelas/independen secara individu dalam menerangkan variasi variabel dependen (Ghozali, 2011:98). Uji ini dilakukan untuk mengetahui apakah tiap variabel bebas yaitu kapasitas sumber daya manusia, dan pengendalian intern akuntansi berpengaruh positif terhadap kualitas informasi akuntansi pada pelaporan keuangan Satuan Kerja Perangkat Daerah (SKPD) Kabupaten Gianyar.

\section{IV.HASIL PENELITIAN DAN PEMBAHASAN}

Penelitian ini dilakukan untuk mengetahui pengaruh kapasitas sumber daya manusia, dan pengendalian intern akuntansi berpengaruh positif terhadap kualitas informasi akuntansi pada pelaporan keuangan Satuan Kerja Perangkat Daerah (SKPD) Kabupaten Gianyar. Tiap-tiap SKPD memiliki susunan organisasi yang berbeda-beda. Contoh susunan organisasi dari salah satu SKPD yaitu Dinas Pendapatan Daerah Kabupaten Gianyar berdasarkan Peraturan Daerah Kabupaten Gianyar No. 6 tahun 2008 tentang Organisasi dan Tata Kerja Perangkat Daerah.

Sampel dari penelitian ini adalah 32 kantor Satuan Kerja Perangkat Daerah (SKPD) Kabupaten Gianyar yang melaksanakan fungsi akuntansi/ penatausahaan keuangan. Responden yang digunakan dalam penelitian ini adalah kepala bagian keuangan pada Satuan Kerja Perangkat Daerah (SKPD) Kabupaten Gianyar. Masing-masing SKPD dikirim satu kuesioner, dimana koesioner tersebut dikirim langsung ke masing-masing SKPD. Adapun hasil kuisioner dalam bentuk data ordinal dari masing-masing responden dapat dilihat pada lampiran 3, 4, 5, 6 dan dalam bentuk data interval dapat dilihat pada lampiran $7,8,9,10$ Berikut rincian pengiriman dan penerimaan kuesioner dapat dilihat pada Tabel 1

Tabel 1 Rincian Pengiriman dan Penerimaan Kuesioner

\begin{tabular}{lc}
\hline \multicolumn{1}{c}{ Keterangan } & Jumlah \\
\hline Kuesioner yang disebar & 32 \\
Kuesioner yang kembali & 32 \\
Kuesioner yang digunakan & 32 \\
\hline
\end{tabular}

Sumber: Data diolah, 2017

Tabel 1 menunjukkan bahwa jumlah kuesioner yang disebar sebanyak 32 kuesioner yang dikirim secara langsung oleh peneliti. Dari kuesioner yang disebarkan tersebut, yang digunakan dalam penelitian ini adalah sebanyak 32 kuesioner dimana seluruh kuesioner terebut kembali dan layak digunakan dengan persentase 100 persen. Selanjutnya karakteristik sampel responden dapat dilihat pada Tabel 2 . 
Tabel 2 Karakteristik Sampel $(\mathrm{n}=32)$

\begin{tabular}{|c|c|r|}
\hline Karakteristik & Jumlah & \% \\
\hline Usia: & 1 & 3,125 \\
$\leq 30$ tahun & 10 & 31,250 \\
$31-40$ tahun & 10 & 31,250 \\
$41-50$ tahun & 11 & 34,375 \\
$\geq 51$ tahun & 17 & \\
\hline Jenis Kelamin: & 15 & 53,125 \\
Pria & 2 & 46,875 \\
Wanita & 1 & 6,250 \\
\hline Pendidikan: & 22 & 3,125 \\
SMA & 7 & 68,750 \\
D3 & & 21,875 \\
S1 & 31 & 96,875 \\
S2 & 0 & 0 \\
\hline Masa Kerja: 10 tahun & 1 & 3,125 \\
\hline $11-20$ tahun & & \\
\hline
\end{tabular}

\section{1) Hasil Pengujian Instrumen}

a. Uji Validitas

Suatu kuesioner dikatakan valid jika pernyataan pada kuesioner mampu untuk mengungkapkan sesuatu yang akan diukur oleh kuesioner tersebut.

Tabel 3 Hasil Uji Validitas

\begin{tabular}{|c|c|c|c|c|}
\hline No & Instrumen & $\begin{array}{c}\text { Item Pern- } \\
\text { yataan }\end{array}$ & $\begin{array}{c}\text { Koefisien } \\
\text { Korelasi }\end{array}$ & Keterangan \\
\hline \multirow[t]{10}{*}{1} & Kapasitas Sumber Daya & $\mathrm{X} 1.1$ & 0,904 & Valid \\
\hline & Manusia & $\mathrm{X} 1.2$ & 0,813 & Valid \\
\hline & & $\mathrm{X} 1.3$ & 0,831 & Valid \\
\hline & & $\mathrm{X} 1.4$ & 0,732 & Valid \\
\hline & & $\mathrm{X} 1.5$ & 0,879 & Valid \\
\hline & & $\mathrm{X} 1.6$ & 0,833 & Valid \\
\hline & & $\mathrm{X} 1.7$ & 0,857 & Valid \\
\hline & & $\mathrm{X} 1.8$ & 0,835 & Valid \\
\hline & & $\mathrm{X} 1.9$ & 0,871 & Valid \\
\hline & & $\mathrm{X} 1.10$ & 0,870 & Valid \\
\hline \multirow[t]{12}{*}{2} & Pengendalian Intern & $\mathrm{X} 3.1$ & 0,948 & Valid \\
\hline & Akuntansi & $\mathrm{X} 3.2$ & 0,900 & Valid \\
\hline & & $\mathrm{X} 3.3$ & 0,775 & Valid \\
\hline & & $\bar{X} 3.4$ & 0,724 & Valid \\
\hline & & $\mathrm{X} 3.5$ & 0,946 & Valid \\
\hline & & X3.6 & 0,793 & Valid \\
\hline & & $\mathrm{X} 3.7$ & 0,865 & Valid \\
\hline & & $\mathrm{X} 3.8$ & 0,775 & Valid \\
\hline & & X3.9 & 0,918 & Valid \\
\hline & & $\mathrm{X} 3.10$ & 0,895 & Valid \\
\hline & & $\mathrm{X} 3.11$ & 0,928 & Valid \\
\hline & & $\mathrm{X} 3.12$ & 0,919 & Valid \\
\hline
\end{tabular}

Berdasarkan Tabel 3 dapat dilihat bahwa koefisien korelasi dari masing-masing pertanyaan dalam kuesioner lebih besar dari 0,3 sehingga dapat disimpulkan bahwa pertanyaan dalam kuesioner tersebut layak digunakan dalam penelitian. b. Uji Reliabilitas

Reliabel berarti seberapa besar suatu pengukuran dapat dipercaya. Suatu kuesioner dikatakan reliabel atau handal jika seseorang terhadap pernyataan tersebut konsisten atau stabil dari waktu ke waktu. 
Tabel 4 Hasil Uji Reliabilitas

\begin{tabular}{lcc}
\hline \multicolumn{1}{c}{ Variabel Penelitian } & Croncbach's Alpha & Keterangan \\
\hline Kapasitas Sumber Daya Manusia & 0,955 & Reliabel \\
\hline Pengendalian Intern Akuntansi & 0,970 & Reliabel \\
\hline
\end{tabular}

Berdasarkan Tabel 4 dapat dilihat bahwa nilai $\mathrm{R}$ alpha hitung masing-masing variabel lebih besar dari $\mathrm{R}$ alpha tabel 0,7 sehingga dapat disimpulkan bahwa pernyataan dalam kuesioner penelitian ini memiliki tingkat reliabilitas yang baik dan dapat digunakan lebih lanjut dalam penelitian ini.

\section{2) Hasil Uji Asumsi Klasik}

a) Uji Normalitas

Uji normalitas bertujuan untuk menguji apakah dalam model regresi, variabel pengganggu atau residual memiliki distribusi normal (Ghozali, 2011:160).

Tabel 5 Hasil Uji Normalitas

\begin{tabular}{ccc}
\hline Variabel Terikat & Kolmogorov-Smirnov $\mathbf{Z}$ & Asymp. Sig \\
\hline Kualitas Informasi Akuntansi & 0,668 & 0,764 \\
\hline
\end{tabular}

Berdasarkan Tabel 5 dapat dilihat uji Kolmogorov-Smirnov yang menghasilkan koefisien Kolmogorov-Smirnov Z sebesar 0,668 dengan Asymp. Sig sebesar 0,764. Nilai signifikansi lebih besar dari alpha $(\alpha=0,05)$ maka dapat diinterpretasikan bahwa model uji telah memenuhi asumsi normalitas. b) Uji Heteroskedastisitas

Uji heteroskedastisitas bertujuan menguji apakah dalam model regresi terjadi ketidaksamaan variance dari residual suatu pengamatan ke pengamatan yang lain. Untuk mendeteksi ada atau tidaknya heteroskedastisitas digunakan model Glejser.

Tabel 6 Hasil Uji Heteroskedastisitas

\begin{tabular}{|c|c|c|}
\hline \multirow{2}{*}{ Variabel Penelitian } & \multicolumn{2}{|c|}{ Kualitas Informasi Akuntansi } \\
\cline { 2 - 3 } & t hitung & Sig. \\
\hline Kapasitas Sumber Daya Manusia & $-0,140$ & 0,890 \\
\hline Pengendalian Intern Akuntansi & $-1,921$ & 0,065 \\
\hline
\end{tabular}

Berdasarkan Tabel 6 dapat dilihat bahwa nilai signifikansi masing-masing variabel lebih besar dari 0,05 yang berarti bahwa secara statistik berarti variabel tidak berpengaruh secara signifikan statistik karena $p$-value lebih besar dari 0,05 berarti variabel tersebut bebas heteroskedastisitas. c) Uji Multikolinearitas

Uji multikoliniearitas bertujuan untuk menguji apakah model regresi ditemukan adanya korelasi antar variabel bebas (independen) (Ghozali, 2011:105).

Tabel 7 Hasil Uji Multikolinearitas

\begin{tabular}{|l|c|c|}
\hline \multirow{2}{*}{\multicolumn{2}{|c|}{ Variabel }} & \multicolumn{2}{c|}{ Kualitas Informasi Akuntansi } \\
\cline { 2 - 3 } & \multicolumn{2}{|c|}{ Collinearity Statistics } \\
\cline { 2 - 3 } & Tolerance & VIF \\
\hline Kapasitas Sumber Daya Manusia & 0,863 & 1,159 \\
\hline Pengendalian Intern Akuntansi & 0,853 & 1,172 \\
\hline
\end{tabular}

Dalam Tabel 4.8 terlihat hasil uji multikolinearitas dengan nilai tolerance masing-masing variabel lebih besar dari 0,1 dan nilai VIF kurang dari 10 , sehingga dapat disimpulkan dalam model regresi tidak terjadi masalah multikolinearitas.

\section{3) Hasil Analisis Regresi Linear Berganda}

Teknik analisis ini digunakan untuk mengetahui ketergantungan suatu variabel terikat terhadap satu atau lebih variabel bebas dengan atau tanpa variabel moderator. Analisis ini juga dapat menduga besar arah dari hubungan tersebut serta mengukur derajat keeratan hubungan antara satu variabel terikat dengan satu atau lebih variabel bebas (Ghozali, 
2011:96). Hasil uji analisis regresi linear berganda disajikan pada Tabel 7 berikut.

Teknik analisis ini digunakan untuk mengetahui ketergantungan suatu variabel terikat terhadap satu atau lebih variabel bebas dengan atau tanpa variabel moderator. Analisis ini juga dapat menduga besar arah dari hubungan tersebut serta mengukur derajat keeratan hubungan antara satu variabel terikat dengan satu atau lebih variabel bebas (Ghozali, 2011:96). Hasil uji analisis regresi linear berganda disajikan pada Tabel 4.9 berikut.

Tabel 8 Hasil Uji Analisis Regresi Linear Berganda

\begin{tabular}{|c|c|c|c|c|c|}
\hline \multirow[t]{2}{*}{ Model } & \multicolumn{2}{|c|}{$\begin{array}{l}\text { Unstandardized } \\
\text { Coefficients }\end{array}$} & \multirow{2}{*}{$\begin{array}{c}\begin{array}{c}\text { Standardized } \\
\text { Coefficients }\end{array} \\
\text { Beta } \\
\end{array}$} & \multirow[t]{2}{*}{$\mathrm{T}$} & \multirow[t]{2}{*}{ Sig. } \\
\hline & $\mathrm{B}$ & Std. Error & & & \\
\hline $\begin{array}{l}\text { Kapasitas Sumber Daya } \\
\text { Manusia }\end{array}$ & 0,815 & 0,156 & 0,583 & 5,244 & 0,000 \\
\hline $\begin{array}{l}\text { Pengendalian Intern } \\
\text { Akuntansi }\end{array}$ & 0,422 & 0,127 & 0,372 & 3,314 & 0,003 \\
\hline Constant & \multicolumn{5}{|c|}{$-14,234$} \\
\hline$F_{\text {hitung }}$ & \multicolumn{5}{|c|}{21,710} \\
\hline Sig. Fhitung & \multicolumn{5}{|c|}{0,000} \\
\hline $\mathrm{R}^{2}$ & \multicolumn{5}{|c|}{0,699} \\
\hline Adjusted $\mathrm{R}^{2}$ & \multicolumn{5}{|c|}{0,667} \\
\hline
\end{tabular}

Sumber: Lampiran 17

Berdasarkan Tabel 4.9 dapat dibentuk persamaan regresi linear berganda sebagai berikut. $\hat{\mathrm{Y}}=-14,234+0,815 \mathrm{X}_{1}+0,422 \mathrm{X}_{2}$

Keterangan

$\begin{array}{ll}\hat{\mathrm{Y}} & =\text { kualitas informasi akuntansi } \\ \mathrm{X}_{1} & =\text { kapasitas sumber daya manusia } \\ \mathrm{X}_{2} & =\text { pengendalian intern akuntansi }\end{array}$

Dari hasil analisis regresi akan diamati Goodness of Fit-nya melalui tiga aspek sebagai berikut.

a) Koefisien Determinasi $\left(\mathrm{R}^{2}\right)$ Koefisien determinasi $\left(\mathrm{R}^{2}\right)$ digunakan untuk mengukur seberapa jauh kemampuan model dalam menerangkan variasi variabel dependen. Nilai $\mathrm{R}^{2}$ memiliki kelemahan, yaitu dengan bertambahnya variabel bebas, nilai $\mathrm{R}^{2}$ akan meningkat walaupun variabel yang ditambahkan tersebut bukan bagian dari model. Untuk menghindari adanya kelemahan ini, maka akan lebih baik menggunakan nilai adjusted $\mathrm{R}^{2}$ (Ghozali, 2011:97). Dari Tabel 4.9 dapat dilihat nilai adjusted $\mathrm{R}^{2}$ sebesar 0,667 . Hal ini berarti 66,7 persen dari variansi kualitas informasi akuntansi pada pelaporan keuangan Satuan Kerja Perangkat Daerah (SKPD) Kabupaten Gianyar dipengaruhi oleh variansi kapasitas sumber daya manusia, pemanfaatan teknologi informasi dan pengendalian intern akuntansi sedangkan sisanya sebesar 33,3 persen dipengaruhi oleh variansi faktor-faktor lain yang tidak dimasukkan atau disebutkan dalam penelitian.

b) Uji F Variabel independen yaitu kapasitas sumber daya manusia, dan pengendalian intern akuntansi berpengaruh signifikan secara statistik terhadap kualitas informasi akuntansi pada pelaporan keuangan Satuan Kerja Perangkat Daerah (SKPD) Kabupaten Gianyar.

c) Uji t Variabel kapasitas sumber daya manusia, pemanfaatan teknologi informasi dan pengendalian intern akuntansi memiliki signifikansi t $<0,05$. Berdasarkan hasil koefisien determinasi, uji $\mathrm{F}$ dan uji t yang diperoleh dari análisis regresi, maka model yang digunakan dalam penelitian ini dikatakan fit.

\section{4) Hasil Uji Hipotesis}

Pengujian hipotesis dapat dilihat dari signifikan hasil uji t pada Tabel 4.9 dengan menggunakan bantuan program IBM SPSS 19 dan dengan membandingkan $t_{\text {hitung }}$ dengan $t_{\text {tabel. }}$. Pembahasan hasil uji hipotesis adalah sebagai berikut.

1) Pengujian Hipotesis $\mathrm{H}_{1}$ : Kapasitas sumber daya manusia $\left(\mathrm{X}_{1}\right)$ berpengaruh positif terhadap kualitas informasi akuntansi (Y) pada pelaporan keuangan Satuan Kerja Perangkat Daerah (SKPD) Kabupaten Gianyar. Hasil uji menunjukkan bahwa nilai $\mathrm{t}_{\text {hitung }}(5,244)>\mathrm{t}$ tabel $=1,699$ dengan signifikansi $0,003<0,05$. Jadi, $\mathrm{H}_{0}$ dapat ditolak dan $\mathrm{H}_{1}$ diterima yang berarti kapasitas sumber daya manusia berpengaruh positif terhadap kualitas informasi akuntansi pada pelaporan keuangan Satuan Kerja Perangkat Daerah (SKPD) Kabupaten Gianyar. Hasil ini mendukung hasil penelitian Andriani (2010) dan Winidyaningrum (2010) yang menunjukan bahwa kapasitas sumber daya manusia berpengaruh positif terhadap kualitas 
informasi akuntansi.

2) Pengujian Hipotesis $\mathrm{H}_{3}$ : Pengendalian intern akuntansi $\left(\mathrm{X}_{3}\right)$ berpengaruh positif terhadap kualitas informasi akuntansi (Y) pada pelaporan keuangan Satuan Kerja Perangkat Daerah (SKPD) Kabupaten Gianyar. Hasil uji menunjukkan bahwa nilai $\mathrm{t}_{\text {hitung }}(3,314)>\mathrm{t}_{\text {tabel }}$ $=1,699$ dengan signifikansi 0,003 $<0,05$. Jadi, $\mathrm{H}_{0}$ dapat ditolak dan $\mathrm{H}_{1}$ diterima yang berarti pengendalian intern akuntansi berpengaruh positif terhadap kualitas informasi akuntansi pada pelaporan keuangan Satuan Kerja Perangkat Daerah (SKPD) Kabupaten Gianyar. Hasil ini mendukung hasil penelitian Andriani (2010) dan Winidyaningrum (2010), yang menunjukan bahwa pemanfaatan teknologi informasi berpengaruh positif terhadap kualitas informasi akuntansi.

\section{SIMPULAN DAN SARAN}

\section{A. SIMPULAN}

Berdasarkan pembahasan hasil penelitian pada bab sebelumnya, didapat simpulan sebagai berikut.

1) Kapasitas sumber daya manusia berpengaruh positif terhadap kualitas informasi akuntansi dengan tingkat keyakinan 95 persen. Ini berarti semakin tinggi kapasitas sumber daya manusia, maka semakin tinggi pula kualitas informasi akuntansi pada pelaporan keuangan Satuan Kerja Perangkat Daerah (SKPD) Kabupaten Gianyar.

2) Pengendalian intern akuntansi berpengaruh positif terhadap kualitas informasi akuntansi dengan tingkat keyakinan 95 persen. Ini berarti semakin tinggi pengendalian intern akuntansi, maka semakin tinggi pula kualitas informasi akuntansi pada pelaporan keuangan Satuan Kerja Perangkat Daerah (SKPD) Kabupaten Gianyar.

\section{B. SARAN}

Berdasarkan kesimpulan diatas, maka saran yang dapat diberikan adalah sebagai berikut.

1) Dari hasil penelitian yang menunjukan bahwa kapasitas sumber daya manusia, pemanfaatan teknologi informasi dan pengendalian intern akuntansi berpengaruh positif terhadap kualitas informasi akuntansi pada pelaporan keuangan Satuan Kerja Perangkat Daerah (SKPD) Kabupaten Gianyar, maka disarankan kepada SKPD Kabupaten Gianyar agar bisa meningkatkan kapasitas sumber daya manusia yang berkualitas, memaksimalkan pengendalian intern secara efektif agar opini BPK untuk Kabupaten Gianyar yang Wajar Dengan Pengecualian (WDP) bisa menjadi Wajar Tanpa Pengecualian (WTP).
2) Berdasarkan hasil penelitian, didapat bahwa masih ada 33,3 persen faktor lain yang tidak dimasukkan dalam model. Hasil penelitian ini diharapkan mampu mendorong para peneliti selanjutnya untuk mengamati faktor-faktor lain yang dapat mempengaruhi kualitas informasi akuntansi pada pelaporan keuangan Satuan Kerja Perangkat Daerah (SKPD) Kabupaten Gianyar.

\section{DAFTAR PUSTAKA}

Abidin dan Endri. 2009. Kinerja Efisiensi Teknis Bank Pembangunan Daerah: Pendekatan Data Envelopment Analysis (DEA). Jurnal Akuntansi Dan Keuangan, 11(1): h: 21-29.

Aksara dan Handayani, L. 2005. Identifikasi Karakteristik-Karakteristik Keahlian Audit Profesi Akuntan Publik Pada Kantor Akuntan Publik Di Denpasar. Jurnal Riset Akuntansi Aksio$m a, 4(2)$ : h: 43-56.

Alim dan Purwanti, L. 2007. Pengaruh Kompetensi Dan Independensi Terhadap Kualitas Audit Dengan Etika Auditor Sebagai Variabel Moderasi. Simposium Nasional Akuntansi X, Unhas Makassar 26-28 Juli 2007.

Amudo, Angela. dan Inanga, E. 2009. Evaluation of Internal Control Systems: A Case Study from Uganda. International Research Journal of Finance and Economics, 27: h: 124-144.

Arens, A, Elder, J dan Beasley, S. 2008. Auditing dan Jasa Assurance. Jakarta: Erlangga.

Asikin, B. 2006. Pengaruh Sikap Profesionalisme Internal Auditor Terhadap Peranan Internal Auditor dalam Pengungkapan Temuan Audit. Jurnal Bisnis Manajemen dan Ekonomi, 7(3): h: 792-810.

Astika, Ida Bagus Putra. 2010. Teori Akuntansi. Konsep-Konsep Dasar Akuntansi Keuangan. Universitas Udayana.

Badera, I Dewa Nyoman. 2008. Pengaruh Kesesuaian Hubungan Corporate Governance Dengan Budaya Koperasi Terhadap Kinerja Perusahaan.

Bastian, I. 2001. Akuntansi Sektor Publik di Indonesia. Yogyakarta: BPFE.

Bia, "Kredit Macet LPD Bergerak Liar * Dekati 10 Persen", www.bisnisbali.com/2011/01/27/news/ perbankan/m.html (Akses 12 Juli 2012).

Brewster, Matthew. 2007. Monitoring Processes and Internal Control Adequacy: Continuous Monitoring Within a Microsoft Access Database. ISACA Journal, Vol. 6.

Budhananda, Ida Ayu. 2011. Pengaruh Struktur Pen- 
gendalian Internal Dalam Meningkatkan Efisiensi Penyaluran Kredit Pada Lembaga Perkreditan Desa (LPD) di Kabupaten Badung. Skripsi. Universitas Udayana.

Budi, Untung. 2005. Kredit Perbankan di Indonesia. Yogyakarta: Andi.

Bupati Badung, Peraturan Pemerintah Kabupaten Badung No. 19 Tahun 2001 tentang LPD.

Bupati Badung, Perda Nomor 140 tahun 2002 tanggal 31 Desember 2002, tentang Petunjuk Teknis Operasional Lembaga Perkreditan Desa (LPD).

Colbert, J. L. 1993. Discovering Opportunities for a New Working Relationship Between Internal and External Auditor, The National Public Accountant and Finance, 38(1): h: 69-83.

Cosmin, Eugen. 2007. Enhancing Assets' Protection Through An Adequate Monitoring Of Internal Control System By Internal Audit. Journal of Universitatea "Babe_Bolyai" Cluj-Napoca Facultatea de tiin e Economice $i$ Gestiunea Afacerilor, h: 491-497.

Darsana. 2009. Pasar Keuangan dan Lembaga Keuangan. Buku Ajar.

Dewi, Chandra. 2009. Faktor-Faktor Yang Mempengaruhi Strategi Pemberian Kredit Dan Dampaknya Terhadap Non Performing Loan. Tesis

Diatmika, I. N. G. A. 2010. Evaluasi Struktur Pengendalian Intern Terhadap Kredit di Lembaga Perkreditan Desa (LPD) Desa Pakraman Pemogan-Denpasar Selatan. Jurnal Ilmiah Akuntansi Manajemen, 3(5): h: 73-89.

Dunil, Z. 2005. Risk-Based Audit (Dalam Pemeriksaan Perkreditan Bank Umum). Jakarta: PT. INDEKS.

Elbannan. 2008. Quality of internal control over financial reporting, corporate governance and credit ratings. International Journal of Disclosure and Governance, 6(2): h: 127-149.

Firdaus, R. dan Ariyanti, M. 2008. Manajemen Perkreditan Bank Umum. Bandung: Alfabeta.

Ghozali, Imam. 2009. Aplikasi Analisis Multivariate dengan Program SPSS. Edisi Kedua. Semarang: Universitas Diponegoro.

Halim, Abdul. 2008. Auditing 1 (Dasar-Dasar Audit Laporan Keuangan). Edisi Keempat. Yogyakarta: UPP AMP YKPN.

Handoko, Hani. 2011. Manajemen Edisi 2. Yogyakarta: BPFE - Yogyakarta.

Hartadi, Bambang. 2004. Auditing. Edisi Kedua. Yogyakarta: BPFE-Yogyakarta.

Herawaty, A dan Susiana. 2007. Analisis Pengaruh
Independensi, Mekanisme Corporate Governance, Dan Kualitas Audit Terhadap Integritas Laporan Keuangan. Simposium Nasional Akuntansi X. Unhas Makassar 26-28 Juli 2007.

Idrus. 2007. Pengaruh Internal Audit Terhadap Efektivitas Pengendalian Intern Kas Pada PT. Adi Guna. Jurnal A kuntansi, 3(2): h: 110-122.

Iriyadi. 2004. Peranan Internal Auditor dalam Menunjang Efektivitas Sistem Pengendalian Intern Penggajian pada PT. Organ Jaya. Jurnal Ilmiah Ranggagading, 4(2): h: 15-27.

Istanti. 2009. Faktor-Faktor Yang Mempengaruhi Pengungkapan Sukarela Modal Intelektual (Studi Empiris Pada Perusahaan Non Keuangan Yang Listing di BEI). Tesis. Universitas Diponogoro.

Jensen dan William H. Meckling. 1976. Theory of the Firm: Managerial Behavior, Agency Costs and Ownership Structure. Journal of Financial Economics, 3(4): h: 305-360.

Johnson, B. dan Kell. 2002. Modern Auditing. Edisi Ketujuh. Jakarta: Erlangga.

Joan E. Grusec. 1992. Social Learning Theory and Developmental Psychology: The Legacies of Robert Sears and Albert Bandura. Journal Developmental Psychology, 28(5): h: 776786.

Jokipii, Annukka. 2009. Determinants And Consequences Of Internal Control In Firms: A Contingency Theory Based Analysis. Journal Management Governance, 14: h: 115-144.

Jusup, A. H. 2001. A uditing. Yogyakarta: STIE.

Kalbers, Lawrence P. dan Fogarty, Timothi J. 1995. Profesionalism and Its Consequences: A Study of Internal Auditors, Auditing: A Journal of Practice and Theory, 14: 64-86.

Kasmir. 2008. Bank dan Lembaga Keuangan Lainnya. Jakarta: PT. Raja Grafindo Persada.

Mahmudi. 2010. Manajemen Kinerja Sektor Publik. Edisi Kedua. Yogyakarta: Unit Penerbit dan Percetakan Sekolah Tinggi Ilmu Manajemen YKPN.

Mahsun, M. 2006. Pengukuran Kinerja Sektor Publik. Yogyakarta: BPFE.

Mardiasmo. 2002. Akuntansi Sektor Publik. Yogyakarta: Penerbit Andi.

Mayangsari, S. 2003. Pengaruh Keahlian Audit dan Independensi terhadap Pendapat Audit: Sebuah Kuasieksperiman. Jurnal Riset Akuntan- 
si Indonesia. 6(1): h: 1-22.

Mertha, M. dan Budiartha, K. 2009. Profesionalisme Badan Pengawas mendorong Kemajuan LPD. Buletin Studi Ekonomi, 14(3): h: 249-256.

Miglietta, A.; Anaclerio, M dan Bettinelli, C. 2007. Internal Audit Risk Assessment And Legal Risk: First Evidence In The Italian Experience. Journal Corporate Ownership \& Control, 4(4): h: 50-58.

Muljono, T. P. 1999. Aplikasi Manajemen Audit Dalam Industri Perbankan. Edisi Pertama. Yogyakarta: BPFE.

Mulyadi. 2002. Auditing. Edisi Keenam. Jakarta: Salemba Empat.

Munawir, H.S. 2008. Auditing Modern Buku 1 Edisi 2. Yogyakarta: BPFE Yogyakarta.

Murtanto dan Gudono. 1999. Identifikasi Karakteristik-Karakteristik Keahlian Audit. Jurnal Riset Akuntansi Indonesia, 2(1): h: 37-51. Yogyakarta : STIE.

Peraturan Daerah Provinsi Bali Nomor 8 Tahun 2002, Tentang Lembaga Perkreditan Desa.

Peraturan Daerah Provinsi Bali Nomor 3 Tahun 2007, Perubahan Atas Peraturan Daerah Provinsi Bali Nomor 8 Tahun 2002 Tentang Lembaga Perkreditan Desa.

Permadi, Bayu. 2010. Pengaruh Penerapan Struktur Pengendalian Intern Terhadap Kinerja Perkreditan pada Lembaga Perkreditan Desa di Kota Denpasar. Skripsi. Universitas Udayana.

Pratiwi, M dan Syahelmi. 2009. Peranan Lingkungan Pengendalian terhadap Pemberian Kredit pada PT. Bank Rakyat Indonesia (Persero) Tbk. Cabang Putri Hijau Medan, Jurnal Akuntansi 28.

Purnamadewi, E. 2010. Pengaruh Efektivitas Struktur Pengendalian Internal Pada Kinerja Perkreditan Lembaga Perkreditan Desa Di Kecamatan Denpasar Utara. Skripsi. Universitas Udayana.

Primastuti, Anindita. 2006. Kualitas Sistem Pengendalian Intern Sebagai Penentu Tingkat Kepercayaan Laporan Keuangan Suatu Pemerintah Daerah. Jurnal Widyapraja, 36(3).

Puspa, Ari. 2010. Pengaruh komponen struktur pengendalian intern dan keahlian profesional badan pengawas terhadap efisiensi pemberian kredit Lembaga Perkreditan Desa (LPD) di Kecamatan Dawan Klungkung. Skripsi. Universitas Udayana.

Ramadhani, Zaini Widya; Sucipto. 2009. Pengendalian Internal Sebagai Alat dalam Meningkatkan Kualitas Kredit pada Bank perkreditan Rakyat Indonesia Tbk. Cabang Medan Putri
Hijau. Jurnal A kuntansi 28.

Ramantha, I. W. 2006. Menuju LPD Sehat. Buletin Studi Ekonomi, 11(1): h: 46-52.

Ratnadi, dan Desyanti, A. 2008. Pengaruh Independensi, Keahlian Profesional, dan Pengalaman Kerja Pengawas Intern Terhadap Efektivitas Penerapan Struktur Pengendalian Intern Pada Bank Perkreditan Rakyat di Kabupaten Badung. Audi Jurnal Akuntansi Dan Bisnis, 3 (1).

Rittenberg; Larry; Frank Landes dan Charles. 2007. Internal Control Guidance Not Just a Small Matter. Journal of A ccountancy, 3(46): h: 4850 .

Rivai, V dan Veithzal, A. P. 2006. Credit Management Handbook. Jakarta: PT. RajaGrafindo Persada.

Roudhah; Yahya dan Idhar. 2009. Analisis Sistem Pengawasan Intern Penerimaan dan Pengeluaran Kas pada Kantor Dinas Pengelola Keuangan dan Kekayaan Daerah (DPPKD) Kab. Aceh Timur. Jurnal Akuntansi 45.

Suartana, I. W. 2009. Arsitektur Pengelolaan Risiko Pada Lembaga Perkreditan Desa (LPD). Bali: Udayana University Press.

Sugiyono. 2007. Metode Penelitian Bisnis. Bandung: Alfabeta.

2009. Metode Penelitian Bisnis. Bandung: Alfabeta.

Sukerta, A. 2010. Pengaruh Penerapan Struktur Pengendalian Intern dan Keahlian Profesional Badan Pengawas Pada Efisiensi Pemberian Kredit Lembaga Perkreditan Desa (LPD) di Kota Denpasar. Skripsi. Universitas Udayana.

Takahiro, S. 2012. Comparison of Internal Control Systems in Japan and China. International Journal of Business Administration, 3(1): h:66-73.

Wahyudi, Hendro dan Ainul, A. 2006. Pengaruh Profesionalisme Auditor Terhadap Tingkat Materialitas Dalam Pemeriksaan Laporan Keuangan. Simposium Nasional Akuntansi 9 Padang, Padang, 23-26 Agustus 2006.

Widodo, Eko. 2002. Pengendalian Direktur Pemasaran Kap: Suatu Sintesa Lima Teori. Jurnal Akuntansi dan Manajemen, h: 1-13.

Wirawan, Nata. 2002. Cara Mudah Memahami Statistik 2 (Statistik Inferensia) Untuk Ekonomi dan Bisnis. Edisi Kedua. Denpasar: Keraras Emas. 